\title{
From the Persian Gulf to Kosovo - War Journalism and Propaganda
}

I Stig A. Nobrstedt, Sophia Kaitatzi-Whitlock, Rune Ottosen and Kristina Riegert

\begin{abstract}
A B S T R A C T
- The article reports findings from a pilot study of the discourse on Kosovo in four leading dailies from four countries: Greece, Norway, Sweden and the UK. A combined discourse and propaganda analysis approach is applied to the first three days' coverage of the NATO bombing campaign, with the aim of studying how the various national/local contexts influenced the media discourse's relationship to the propaganda discourse in the conflict. This problematic is relevant for the current discussion on globalization and superpower dominance in connection with transnational war journalism.
\end{abstract}

Key Words globalization, Kosovo war, media war, propaganda discourse, recontextualization

\section{Introduction}

How did the media in democratic countries report a conflict in which leading democratic states claimed the moral right to violate international

Stig A. Nohrstedt is Professor in the Department of Humanities, Örebro University, S-701 82 Örebro, Sweden. [email: stig-arne.nohrstedt@hum.oru.se]. Sophia Kaitatzi-Whitlock is lecturer in Communication in the Department of Journalism and Mass Media at the Aristotle University of Thessaloniki, Greece. Rune Ottosen is Professsor of Journalism in the Faculty of Journalism, Library and Information Science, Oslo College, Norway. Kristina Riegert is lecturer in Journalism and Electronic Media at the University College of South Stockholm, Sweden.

European Journal of Communication Copyright (C) 2000 SAGE Publications (London, Thousand Oaks, CA and New Delhi), Vol 15(3): 383-404. [0267-3231(200009)15:3;383-404;013854] 
conventions and to create peace by bombs? That is the general problematic in relation to the Kosovo conflict which we address in this article. In this endeavour our approach is based on propaganda theory and discourse analysis. According to a well-known definition, propaganda is 'the deliberate and systematic attempt to shape perceptions, manipulate cognitions, and direct behavior to achieve a response that furthers the desired intent of the propagandist' (Jowett and O'Donnell, 1992: 4). This definition emphasizes a process perspective. Therefore in our view analyses of media war coverage should relate the media content to propaganda flows and activities in order to be contextually relevant and realistic.

It will also be noticed that 'propaganda' is not used here as in ordinary practice — only as a derogatory label to the enemy's information for being untruthful and unreliable in contrast to one's own side in a conflict. To use 'propaganda' exclusively with reference to one party would actually be to confuse the role of the analyst with the role of the propagandist.

\section{Propaganda and media wars}

Like modern warfare, war journalism is not only made on the battleground but also on the fields of propaganda. Beside the 'real' war there is also a 'media war' (e.g. Taylor, 1997: 119). The context for war correspondents and media coverage of military operations in international conflicts is flooded by propaganda. Almost every news source, PR officer or politician have, in one way or the other, vested interests in relation to the conflict and will only inform about things that presumably support their strategic and tactical objectives. Another typical pattern for war propaganda is that it describes the actual conflict in a radically polarized way - as a struggle between the 'good guys and the bad guys' and in black and white. So, a discourse dominated by propaganda will consequently only allow two positions: for or against. This usually applies to both sides in the conflict, the only difference being that the positive and negative poles are switched. Attempts or claims to take a third position - a distanced, neutral or critical standpoint — will be effectively suppressed.

These features were observed in the Kosovo conflict. On both sides huge efforts were made to win over public opinion and to elicit legitimacy and support for the warfare. NATO and its member states claimed to represent the 'world community' and their interest in peace and humanitarian values. Those who questioned this were accused of 
siding with Milosevic. On the other side in the conflict, Serb propaganda described the NATO operation as aggressive and fascist, beyond all moral and international law. Serbs, including journalists and the media, who tried to take an independent position towards the Belgrade regime felt the logic of the propaganda discourse: either you defend your country or you are a traitor and fifth columnist (Goff, 1999).

\section{Challenges for media studies}

At the same time this has been a conflict of great complexity, not very easy to understand and describe for journalists (or others). The NATO bombings, which at least initially were said to be aiming at forcing Milosevic to accept the so-called peace agreement in Rambouillet and to stop the 'ethnic cleansing' in Kosovo, rather escalated the Yugoslavian resistance and strengthened Milosevic's position in the short term and simultaneously resulted in unprecedented floods of escaping Kosovo Albanians. These effects suggest that the NATO strategy was not only contradictory, but that the alliance also had great problems in making their actions legitimate. The UN charter will only allow military intervention on a sovereign nation-state's territory provided that the Security Council has approved it. NATO did not have any such UN mandate in Kosovo. Nevertheless, the operations were declared to be in the spirit of the UN charter and exclusively motivated on humanitarian grounds.

Thus the conflict was both complex and contradictory and associated with fundamental legal and moral legitimation problems, which should have faced any analyst or commentator with substantial difficulties. Not least for journalists and media — with a professional responsibility for correct, fair and independent coverage - this was an enormous task. In order to find out how journalists and the media handled this difficult situation, it is important to take a thorough look at how they covered the Kosovo war, surrounded, as they were, by propaganda.

That research task brings to the forefront analysis of the relations between the propaganda discourse, on the one hand, and the media discourse, on the other. What alternatives are the media offering the audience in this complicated situation, flooded by propaganda and attempts from both sides to exploit journalism with the aim of winning public opinion over? For analytical purposes we have taken Bill Clinton's speeches of 23 and 24 March 1999 as points of departure, assuming that the American president's strategic goal at that stage of the conflict was to 'shape perceptions, manipulate cognitions, and direct behavior' (Jowett 
and O'Donnell, 1992) with international and national opinions as ultimate targets. The immediate target is the journalists and the media.

This, however, does not imply that we have collapsed the distinction between war journalism and war propaganda. The journalistic profession has a choice and some independence from political and military leaders, and the empirical question for our analysis is to what extent media in different national contexts let themselves be used for propaganda purposes, or not. Thus, starting with the conceptual construction of the Kosovo conflict in Clinton's speeches we can study whether the propaganda image penetrated the media coverage in different countries. This is not to say that the propaganda war in this conflict actually started at the point in time when the US president gave these speeches. It is not only a convenient starting point for the analysis, but also a relevant point, because this was the moment when the strategic need to persuade the general public was most acute since the bombing campaign was announced at that time.

\section{A comparative analysis}

In this article we present some preliminary results from a comparative analysis of the media coverage of the first three days of the NATO air strikes in four countries: Greece, Norway, Sweden and the UK. The focus is on the degree to which the propaganda image of the conflict laid out by President Clinton in his speeches on 23 and 24 March, when the first air attacks were launched, was also present in the European media, and also to what extent it was criticized and opposed. This is accomplished by comparing daily newspapers' discourse in these countries in terms of their construction of the following themes: (1) the Clinton speeches; (2) the image of Milosevic; (3) the consequences of the air attacks; and (4) the positioning of the home country, i.e. the media country.

The comparisons are focused on one leading prestige newspaper in each country, i.e. the one with the largest circulation. The method used is a moderated propaganda and discourse analysis, primarily based on what van Dijk has called 'macro-structures' (van Dijk, 1991), here applied in a descriptive way. Thus we have concentrated on headlines, leads and content in the texts as the basic empirical material while using titles and leads in particular as indicators of the discursive framing of the articles. News, editorials, commentaries and feature stories have all been included. 
Critical discourse analysis has several variations, with, for example, one British, one Dutch, one German and one Austrian variant (Wodak et al., 1999). When, for instance, analysing newspaper texts, they are conceived of as discursive acts and social practice in a historical, political and social setting. Thus, critical discourse analysis

... assumes a dialectical relationship between particular discursive acts and the situations, institutions and social structures in which they are embedded: the situational, institutional and social contexts shape and affect discourse, and, in turn, discourses influence social and political reality. In other words, discourse constitutes social practice and is at the same time constituted by it. (Wodak et al., 1999: 8; see also Nohrstedt, 1986)

In this study we concentrate in particular on the relations between the texts and (1) the propaganda activities of the conflicting parties, and (2) the national/local foreign and security-policy contexts of the specific media in the sample. From the globalization discussion we are inspired to explore the 'local appropriation' (Thompson, 1995) and 'recontextualization' (Fairclough, 1995) of meaning in transnational war journalism.

\section{The sample}

Thus the following comparisons are based on three days ${ }^{1}$ of Kosovo coverage in one leading newspaper in each of the four countries: Greece, Norway, Sweden and UK. That we have sampled media from these countries is a strategic choice, considering that our analytical focus is on the importance of the foreign and security policy contexts and the relations to the conflict of the media war discourse. Hence, the sample consists of one leading NATO force (UK); one NATO and Western European Union (WEU) member, who is also a non-EU member state (Norway); one non-NATO, non-WEU member, formerly known as a champion of non-alignment, and now a new EU member state (Sweden); and, finally, one member of all three organizations, NATO, the WEU and $\mathrm{EU}$, and at the same time a country for whom any war in the Balkans produces direct economic, security and welfare liabilities owing to its proximity in the region (Greece). It can be expected that these variations of national political-historical contexts will significantly influence the media coverage, and that, therefore, it is theoretically and analytically productive to compare media images of the war in these countries.

The selected papers are: Ta Nea (Greece), Aftenposten (Norway), Dagens Nyheter (Sweden) and The Daily Telegraph (UK). They have the following characteristics. 
Ta Nea ('The News') is a prestigious national daily, representing the mainstream of political, social and economic life in the country. It is owned by Greece's major media conglomerate, the Lambrakis Corporation, which is very powerful in both economic and political terms. It is one of 22 political dailies (morning and evening newspapers) circulating in Athens and nationwide. It regularly gets the highest daily readership, with circulations of 55,000-60,000 copies per day. Politically, Ta Nea provides support for the governing party, PASOK (Panhellenic Socialist Movement), and particularly for the group centred on its leader, Costas Simitis. It thus expresses a moderate, democratic centre voice.

Aftenposten is a prestige broadsheet newspaper with a circulation of 290,000 on weekdays. It is the biggest morning paper and is owned by the Schibsted company (one of the three major media companies in Norway). It is traditionally a conservative paper supporting the Norwegian political party Hoyre (the Right). Since the breakdown of the party press system, it has positioned itself as an independent centre-right newspaper. It has traditionally been supportive of Norway's membership in NATO.

Dagens Nybeter is the leading prestige morning daily with an 'independent liberal' editorial position. It is also the biggest morning paper, enjoying a circulation figure of 348,000 on weekdays. It belongs to the Bonnier media group and is distributed nationally. In terms of foreign policy Dagens Nybeter has come out strongly for a change from the traditional non-alignment policy to Swedish membership of NATO.

The Daily Telegraph can be characterized as a national quality daily, competing in the same category as The Times, The Independent and The Guardian. Of these national qualities, The Daily Telegraph has consistently had the largest circulation since 1945. According to Brian McNair, The Daily Telegraph has the fifth largest circulation of national newspapers in Britain — only the tabloids have a higher circulation (McNair, 1999: 14; Seymour-Ure, 1996). The Daily Telegraph belongs to the Hollinger group controlled by Conrad Black, which also owns a number of papers in Canada, Israel, Australia and the USA.

\section{Official policy on Kosovo}

Of the countries included in this study, two - Norway and the UK took active part in the NATO operations, but the former only to a minor extent (they supplied fighter planes for support, but were not involved in the actual bombings) while the UK was a major contributor (involved in the bombing campaign as well as in propaganda activities). Greece, 
neighbouring the conflict area, was one of the NATO members not involved in the military operations, and promoted a political and diplomatic solution. Sweden as a non-aligned country did not participate in the NATO operations in any way. As a EU member the Swedish government stood behind the EU declaration on the Kosovo conflict, but did not take a position on the military operations.

\section{The Kosovo propaganda war}

One of the main propaganda battles that took place during the preface to the Kosovo war was about the different peace initiatives. In the preface to the war there were two basic initiatives. The so-called Rambouillet Accord represented the NATO proposal in the conflict. The most problematic part of the draft to an agreement to accept for the Serbian side was Appendix B, which defined the terms for the so-called Multinational Military Implementation Force. The most controversial paragraph reads as follows:

NATO personnel shall enjoy, together with their vehicles, vessels, aircraft, and equipment, free and unrestricted passage and unimpeded access throughout the FRY [Federal Republic of Yugoslavia] including associate airspace and territorial waters. This shall include, but not to be limited to, the right of bivouac, manouver, billet, and utilization of any areas or facilities as required for support, training and operations.

On 23 March the Serbian National Assembly rejected the demand for a NATO military occupation and put forward a counterproposal. It proposed a diplomatic solution under the auspices of the Organisation for Security and Co-operation in Europe (OSCE) and the UN, which included autonomy for Kosovo. The propaganda position on the NATO side was to label Milosevic as unwilling to negotiate and to silence the Serbian counterproposal. On the other hand, the propaganda offensive from the Serb side was to label the Rambouillet Accord a provocation towards an independent country (Chomsky, 1999: 107-9).

Chomsky's interpretation of Rambouillet and its propaganda aftermath has — not surprisingly — been questioned. A balanced account is given by Peter Goff of the International Press Institute, Vienna, who, however, concludes that 'this key issue of whether negotiation possibilities had been fully explored received little media attention' (Goff, 1999: 24).

Whatever conclusion one draws with respect to the importance of the Rambouillet Accord, it is obviously an important moment in the development of the Kosovo conflict, well worth analysing from a 
propaganda point of view. What views were conveyed by the media concerning the conditions of the proposed treaty, and to what degree were the conflicting parties' comments and responses to the breakdown of the negotiations exposed to the general public?

\section{Three perspectives as an analytical instrument}

As a further analytical framework we make distinctions between the following three possible perspectives or discourses on the Kosovo conflict. The first two are basically the propaganda views of the opposing parties, NATO/USA and Yugoslavia. But also a third perspective, a view critical towards the NATO propaganda perspective, can be stipulated. These perspectives are merely used here as ideal types, and different concrete variants are possible and are identified and described in our results.

\section{The NATO/USA image}

Milosevic can only be persuaded by hard methods. For a long time, see, for example, the conflict in Bosnia, he has shown that he takes heed of very little. Therefore the Serb terror against the Kosovo Albanians can only be stopped by a force strong enough to make him give up. Military threat and ultimately air strikes are the only options available if we want to help the persecuted Kosovo people.

\section{The Belgrade view}

The war is the result of US imperialistic aggression. The USA wants to dominate East Europe politically and economically. The EU is also an enemy allied to NATO/USA. The conflict might have been solved if the UN had been allowed to take responsibility in Kosovo. Belgrade also criticizes the NATO interpretation of international law and claims that the bombings are a violation of the national sovereignty of the FRY.

\section{The critical perspective}

Military threats and the bombings are counterproductive and will jeopardize the declared objectives of NATO. They will only encourage the enmity and aggravate the conflict. There is a hidden agenda to the motivation of NATO/USA to use violence. Besides, the bombings are violating international law (the UN charter and the Geneva protocol).

As a point of departure when reading the results from our study of the media discourse which follow, it should be noted that the 
personalization of the conflict is the very kernel of the NATO propaganda image. Namely, that the enemy is the individual Slobodan Milosevic, a person who cannot be trusted on any account. Therefore, negotiations or peace initiatives from his side are only bluffs and attempts to confuse NATO and the rest of the world. In this light, it seems to be an almost exact copy of the propaganda strategy applied in the Gulf War (see, for example, contributions in Bennett and Paletz, 1994).

\section{Media discourses: a cross-national analysis}

The results from our comparative analysis are presented in a thematically structured order in such a way that the most essential aspects of the media discourses from a propaganda point of view will be highlighted. ${ }^{2}$ We start with how the two speeches by President Bill Clinton on 23 and 24 March are mirrored in the media, testing the assumption that they had a framing effect on the media's construction of the conflict image. In the second subsection we deal with the enemy image of Milosevic; in the third, with how the consequences of the bombings were depicted; and in the fourth subsection, with how the media discursively positioned their own nation in relation to the conflict.

\section{Clinton's speeches in the media}

In his two speeches President Clinton obviously wanted to construct an image of the Kosovo conflict around three key elements which (1) established a link between the Second World War Nazi regime and the Belgrade regime; (2) demonized the Yugoslavian President Slobodan Milosevic, not only as a criminal dictator like Hitler, but also as a leader that refused all peace proposals; and (3) reiterated that peace and prosperity in Europe was of central interest for the USA. ${ }^{3}$ In relation to the trichotomy of propaganda-related discourses, the speeches exemplify an elaborated and enforced variant of the NATO/USA propaganda view.

These three elements were particularly exposed in the media. It is of course quite natural to find quotations from the US president's speeches on a major international conflict also in European media. More interesting, however, is the amplification and repetition of these propaganda elements in statements made by domestic leaders, in commentaries written by journalists and in editorials. So the issue is not about straight reporting of the Clinton speeches, but about the ways his argumentation and view on the conflict were taken over and used favourably in the national discourses. The 'new military humanism' with 
its strategy of 'peace bombs' (Chomsky, 1999) is accepted and voluntarily promoted by the media and journalists themselves. That is the case for the Norwegian, the Swedish and the British papers, but not the Greek paper.

For example, in Aftenposten the objective of the bombings is forefronted by a headline on the foreign news page of 25 March: 'NATO Attack to Bring about Peace'. And the lead in the same article quotes Clinton: 'We must stand firm against ethnic violence.' Another article in the Norwegian daily the same day supports the image of Milosevic as uncompromising in an interview with the Norwegian foreign minister, Vollebæk, who tells about his futile last minute efforts in his capacity as chair of the OSCE to convince Milosevic that he must accept the Rambouillet draft.

Another example is an editorial in Dagens Nybeter on 26 March, which develops the argument that only the Serb leader can stop the sufferings: 'Milosevic Can Stop the War'. He has exclusive access to the negotiation instrument. 'He alone can say: We resume the negotiations, and in the same moment bring the bombings to an end.'

In contrast to the Scandinavian papers, The Daily Telegraph does not depict President Clinton as the dominant NATO leader, but rather the British prime minister, Tony Blair. As previously noted, there are grounds for the assumption that the NATO propaganda image of the conflict was developed in close cooperation between London and Washington. Blair emphasizes the justice of the cause, using an emotional and rhetorical style in his statements and televised address which promote the image of 'humanitarian bombings':

We are taking this action for one very simple reason: to damage Serb forces sufficiently to prevent Milosevic from continuing to perpetuate his vile oppression against innocent Albanian civilians. Justice, that is all those poor people, driven from their homes in Kosovo, are asking for. (The Daily Telegraph, 25 March 1999: 1)

The Greek newspaper Ta Nea on 24 March gives a clearly different interpretation of the Clinton speech with its emphasis on the "Many Forgotten Aspects in the Clinton Speech in his Attempts to Lecture on Balkan History'. The article is written by the Washington correspondent, who points out two main flaws in the speech.

First, the initial paragraph of the leading article states:

The raids of the NATO bomber aircrafts against Serbia ... is the repetition of the error, which has been made in other instances with catastrophic results, of [trying to forge] 'peace through disaster'. 
Another criticism is raised against Clinton's argument that Turkey and Greece would be involved on opposite sides in the conflict should NATO not intervene. The Washington correspondent, Notis Papadopoulos, points out that Clinton's presentation is erroneous and not at all convincing, since Greece is not willing to be implicated in a Balkan war unless hostilities crossed its own borders. Papadopoulos implies that such an invocation by Clinton constitutes a provocative and grave rhetorical mistake and that it essentially aims to justify the unjustifiable moves by Washington. The front-page headline of the Greek newspaper Ta Nea on 26 March follows up on its critical position: 'Provocation by Clinton against Greece'.

Consequently, the Greek paper is unique among those selected here for comparison in its openly critical coverage of the Clinton speeches. Whereas the dailies from Norway, Sweden and the UK promote the same 'humanitarian' objectives which are emphasized in the president's argumentation, the Greek newspaper focuses on the pitfalls of the speech. In particular, the hollowness of the counter-factual description of what would happen without NATO intervention is questioned, together with reminders on the risks for the region that the chosen strategy implied.

\section{The image of the enemy: Milosevic}

This is the other element in the NATO propaganda construct which seems to have been uncritically adopted by most of the media studied, irrespective of national context; the exception being again the Greek paper. Some of the examples cited already make clear that the demonization of the Yugoslavian leader was taken up and even exaggerated by the journalists themselves in some cases, but there were also some variations between the papers in that respect.

When the NATO air strikes began the Norwegian daily in an editorial on 25 March, titled 'Norway Joins Attack', states that the operations can be justified by the fact that Milosevic has himself to thank because of 'being the aggressor'. By and large Milosevic plays the role of principal villain in Aftenposten. In one instance, though, the image of enemy is moderated slightly by some comments about his politeness and sense of humour, as revealed in contacts with the Norwegian foreign minister.

The demonization of Milosevic is apparent in Dagens Nybeter too. One example is a 'portrait' of the Serb leader by the journalist Disa Håstad, who describes him as a person obsessed by a psychological drive to become a mythical martyr. The association to Hitler is evident. Like 
the German dictator the end of his days will be: 'In a bunker. Alone with the wife Mira. While the bombs are falling around them, they take poison.' Other examples could be added, but space restrictions make it more interesting to say something about the deviation from the enemy image found in the Swedish discourse. In general a critical discourse is significantly more evident in the Swedish daily compared with the others, with the exception of the Greek paper. For instance in a front-page article, Carl Bildt, ex-coordinator in Bosnia, not only foresees that the conflict will be worsened by the NATO attacks and criticizes the motivations for the bombings expressed by Clinton. He also points out that one has to understand the feelings of President Slobodan Milosevic and his people, when it comes to Kosovo. The province used to be called the cradle of Yugoslavia.

In The Daily Telegraph, there is little to counteract what is clearly an attempt by President Clinton and British leaders to personalize the conflict through the use of terms 'he' and 'his' when describing the Yugoslav side. Phrases such as 'his forces have intensified their attacks, burning down Kosovo Albanian villages and murdering civilians' are simply quoted (25 March). Neither is Clinton's accusation that Milosevic started those 'terrible wars against Croatia and Bosnia' questioned. The Yugoslav president, with his policy of nationalism, is seen to be responsible for the break-up of Yugoslavia, the Serbo-Croat War, the Bosnian War, the repression in Kosovo and the NATO resort to bombings. President Milosevic's consolidation of power is intimately connected with the break-up of Yugoslavia. In an article describing the difficulties the NATO bombing will entail, it is said that Milosevic is 'impervious to other people's pain, the only thing that will hurt him is the loss of his own power' (The Daily Telegraph, 26 March).

The Greek daily Ta Nea does not, however, join the choir of antiMilosevic voices. Nowhere in its coverage between 24 and 26 March is the Serb leader pointed to as the villain of the piece.

\section{Consequences of the bombings}

The humanitarian issue is the centre of all the newspaper discourses studied, but the propaganda implications differ dramatically. If we take the Swedish case, it is clear that concern is with the civilians on both sides, i.e. Serbs as well as Kosovo Albanians. This is not always the case in the other media discourses. What is common, though, with the exception of the Greek daily, are the regrets expressed by the NATO leaders. These regrets are important signifiers of the implied reluctance 
and compassion that they want to express for obvious reasons. To what degree and with what selectivity the sufferings of those to whom the NATO leaders direct their empathy are exposed in the discourses differs between the papers.

In Aftenposten the humanitarian aspects of the bombings for the civilian population in Serbia are not so paramount as in the Greek and the Swedish dailies. The main focus in the news coverage in terms of the effects of the bombing is its military impact. In an article on $25 \mathrm{March}$, titled 'Panic is Spreading', we learn, however, about the implications for the civilians in Kosovo and Serbia. With reference to Serb television we learn that women and children are among the victims of the bombing. There are other critical comments, and they have mainly to do with the issue of the legality of the operations. Furthermore, references are made to oppositional remarks of 41 members of the US Congress and the former Bosnian coordinator, Carl Bildt. The editorial on 25 March ends with a philosophical comment, without actually taking a clear stand on the bombing issue: 'In Kosovo we have seen the choice between evils. Most political leaders hoped to avoid that choice. It is under these circumstances that the actors are driven step by step on a stage where they had not expected to come.' In an editorial on 26 March, Aftenposten includes a more critical analysis under the title 'International Law and the Use of Force'. This is a critical review of the discussion on the war in the Norwegian parliament. Aftenposten also warns of the consequences for the civilian population in Serbia if Milosevic is not brought back to the negotiating table. After a while the bombing might cause 'enormous loss of civilian lives', Aftenposten concludes.

In the Swedish Dagens Nybeter of 24 March, the Kosovo conflict is the top story on the front page. The headline reports that 'NATO Has Ordered Air Strikes', and the lead quotes Richard Holbrooke saying that 'Milosevic has chosen a way the consequences of which he is perfectly conscious'.

But the front page is not only referring to US information sources and comments. In fact, when mentioning the emergency situation in Yugoslavia, a 'recalcitrant' statement by the Serbian parliament is also quoted (see later). More blatant is a comment by the former Bosnian coordinator, also at the time head of the Conservative Party in Sweden, Carl Bildt, who warns that if the bombardment starts 'we will have a fullscale war in Kosovo'. Another rather pessimistic view is also mentioned in this article. The research director and Balkan expert at the Royal United Services Institute for Defence Studies in London, Jonathan Eyal, comments: 'Paradoxically, the bombardment can result in the worst 
humanitarian catastrophe in Kosovo, so far'. Similarly, the headlines the next day underline the hazardous nature of the NATO operations: 'The bombings are a tragedy for Europe'; 'Risk That the Conflict Will Spread'; 'NATO-Attacks Not a Solution'; 'The War is a Great Backlash for the UN'; 'Half a Million Refugees on the Run'; 'Bildt Fears a Prolonged Conflict'.

The theme prevalent in The Daily Telegraph regarding the consequences of the bombing can be summed up by a quote from President Clinton justifying the attack: 'only firmness now can prevent greater catastrophe later'. In other words, aside from a few small articles on the opposition of some British politicians to the attacks, the statements by British leaders as well as the interpretation by reporters support the notion that NATO's credibility is at stake (see, for example, The Daily Telegraph, $26 \mathrm{March}$ ). Not only is the credibility issue addressed outright, it is also supported by statements and references to preventing an aggressor from going unpunished, a familiar theme from the historical lesson of the appeasement of Hitler. ${ }^{4}$ Thus, The Daily Telegraph does not address the issue of possible Serb victims of NATO bombing, only a commentary by Alice Thomson with the title 'Surgical Strikes Are Not the Answer' deals with the possible consequences of the bombing for Kosovo Albanian civilians (24 March).

In Ta Nea, however, the humanitarian motives behind the air strikes are questioned and even categorically denounced. The headline of the paper on 24 March, 'Alarm for Wave of Refugees due to Kosovo', sets the tone. The subtitle, 'Fears of a New Vietnam in Europe', denotes the measure and the analogy of the threat facing the country and the region. This alarming headline is followed by the lead to an article stating the fears of Athens in view of the developments already set in motion by NATO.

The next day, 26 March, the Greek daily expresses even greater doubts: 'The door to the lunatic asylum has been swung open by NATO as it started — without any legal basis — the military action against Serbia while invoking the human rights of the Albanian minority of Kosovo.' This denotes clearly the newspaper's line, which is explicit in almost all the relevant articles. No political justification whatsoever is provided for the NATO action. Neither is the moral mantle accepted. There are no signs of being taken in by the invocation of human rights, which, on the contrary, is regarded as hypocritical. 'Jungle' is the curt title of the short leading article. It asserts directly that there is a hidden agenda involving boundary changes in the area. It claims that 'the change of boundaries is INTENDED [in capital letters in the newspaper] in 
Europe for the first time since World War Two ... not through negotiations but through the brutal violence of the American superpower'. The circumvention of UN procedures is viewed as a disgrace and Kofi Annan is called the 'clerk of Washington'. The provocation of the Clinton reference to a putative eruption of Greek-Turkish hostilities, according to the article, justifies 'every worry [emphasis in the original] for the worst scenario that certain forces will spin out against our region and more concretely against our country:

It is as though Serbia constitutes the experiment for the dissolution of the Helsinki agreements, but also of all the international treaties which guarantee the boundaries of independent and sovereign states.

In a short article a former (PASOK) deputy secretary of the ministry of defence, Nikos Kouris, concludes that we are living in 'a new Middle Ages' as the main actors NATO et al. are acting in contravention of the rules they themselves have set down. He points out the contravention of Article 5 of the Treaty Organisation and the outright violation of the provisions of the UN charter.

\section{Positioning of the bome nation}

The coverage in Aftenposten of the domestic situation is very much linked to the fact that Norway has the presidency in the OSCE and took part in the warfare as a NATO member. Several interviews with politicians underline, however, the political unity within parliament including the leaders of the far left party. Concern for the safety of the Norwegian pilots and their families' worry are also reported from the 'home front'. On 26 March a survey is published under the title: 'Norwegians Support the Bombing', and the conclusion is that 54 percent of the population support the attack.

The Swedish government supported the EU declaration, which put total responsibility on Milosevic and demanded that the Belgrade leaders accept the 'peace efforts of the international community' (Dagens Nybeter, 25 March). However, it is important to point out that Sweden was in a minority of EU members who did not officially support the NATO decision to bomb FRY, due to the lack of a UN Security Council mandate.

The most noticeable pattern in the Swedish discourse with respect to the positioning of Sweden and the Swedes in relation to the Kosovo conflict is their ascribed worries and concerns over civilian casualties and sufferings, and their ambivalence or division in terms of their opinion towards the NATO bombings. Not only are the concerns of the Swedish 
foreign minister cited: 'Lindh very worried about the development', but also the chief of the Swedish armed forces is quoted: 'Supreme Commander Critical to Air Strikes'. Another headline expresses doubts about the operation: 'War Not a Humanitarian Contribution'.

The main critical discourse in The Daily Telegraph asks whether the bombing campaign will work, criticizes NATO for the lack of clear-cut aims, or lambasts the 'half-hearted' policy characteristic of 'western' efforts in the Balkans in the last 10 years (26 March). Most commentators argue that the bombing will not improve the situation for the Kosovo Albanians: the favoured solution being the introduction of ground troops, with one commentator advocating Kosovan independence (26 March). This is an argument for ground troops, for greater rather than less military commitment - air strikes alone will not help the humanitarian situation. While this line of thinking is most clear in commentary pieces, it can also be seen in articles about the domestic debate.

The British press's criticism of the lack of clear objectives is underpinned by references to the critique going on in Washington. President Clinton is described as reluctant (26 March). Far from playing the world's policeman, Clinton is depicted as struggling to win over a sceptical US public with a 'reputation as a leader whose word cannot be trusted', and who has 'scant foreign policy credibility' (26-27 March). ${ }^{5}$ Thus in the discourse represented by The Daily Telegraph, Britain is a more consistent and stronger advocate of a policy that, it is claimed, will finally alleviate the suffering of the Kosovo Albanians.

In Ta Nea on 24 March, as indicated earlier, Greece is positioned among those who have everything to lose from the visibly extensive and advanced war undertakings of NATO. Another element immediately foregrounded is the covert — overt in Greek eyes — plot by NATO to unilaterally suit the demands of the Kosovo Liberation Army, the Kosovo Albanians and the Albanians more broadly rather than taking a balanced, fair and dispassionate third party position.

Athens is presented as flabbergasted and confused over the significance of the Clinton statement about the stability and security of the country and the region. A situation of confusion among both government and pundits is reported as being further aggravated by the fact that even member states to the EU, namely the UK and Germany, gave threatening and provocative warnings to Greece but without there being any justification. Greece was notably warned off any military participation that might result from the NATO intervention in Kosovo.

The Greek paper emphasizes the intimidation being exercised by the stronger NATO members towards a weaker one. However, this weak 
NATO member happens also to be located in the vicinity of the contested region and is therefore directly affected by any action, or inaction. It is particularly affected by all military operations and the use of poisonous weaponry such as the depleted uranium bombs. The main article on 26 March succinctly states that such allegations and warnings by the other NATO states stem from those states' own concerns rather than any real or supposed policies on the part of the Greek state, and aim at making Greece knuckle under. So, this manifest exercise of power by the bigger NATO partners is directly repudiated by the article, notably by demanding that international law be reinstated. Militarily, the article reports, Athens refuses to participate in the NATO operations, i.e. it does not contribute armed forces. However, politically and diplomatically, Athens backs the NATO/US decision. Concurrently, 'it advocates the return to a political solution through negotiations'.

\section{The Serbian parliament's proposal}

Noam Chomsky has claimed that one of the most obvious flaws in the media coverage of the Kosovo conflict, together with the lack of detailed information about the content of the Rambouillet Accord, was the neglect to report on the Serbian parliament's proposition of 23 March on how to resolve the conflict. On both these issues our analyses of the first few days of the actual war support Chomsky's critique: there is no mention of the content of Appendix B of the Rambouillet Accord, and only the Swedish and the Greek newspapers reported on the Serb parliament initiative. But the way it was reported is quite interesting.

In Dagens Nybeter, the Swedish daily, the Serbian declaration is characterized as a 'recalcitrant', and its content is quoted very briefly: 'We do not accept foreign military forces on our territory, not even at the cost of being bombed' (Dagens Nybeter, 24 March). Ta Nea (24 March) reports from Belgrade about the unanimous (consensus) decision in the Serbian parliament not to allow itself to be blackmailed and to reject the veto put on Serbia by NATO: "Holbrook came here to tell us: Either NATO forces or bombings", said the Serbian president Milan Milutinovich.' The Greek daily further notices an indication of Serbian tacit acceptance of a peace force in Kosovo:

Soon after Holbrooke departed from Belgrade the Serbian parliament unanimously decided firstly, not to accept the deployment of NATO forces, and secondly to examine the size and the character of an international force presence in the country 'after the achievement of a political agreement about this Serbian province'. 


\section{Conclusions}

In the theoretical debate about globalization it has been argued that the transnational flow of media products is associated with local appropriations of meaning. In this pilot study a combined discourse and propaganda analysis of four leading newspapers in Greece ( $\mathrm{Ta} \mathrm{Nea}$ ), Norway (Aftenposten), Sweden (Dagens Nybeter) and the UK (The Daily Telegraph) has been applied, with a theoretical focus on the variety of 'national' images in relation to the propaganda views that were promoted by the parties involved. Considering the composition of our sample of newspapers, strategically selected to include European dailies from both NATO and non-NATO member states and from both EU and non-EU countries, and also NATO members with different degrees of involvement in and distance from the Kosovo conflict, the purpose of the study is to explore the impact of the national political and historical context on the media discourse's relation to the propaganda struggle in the conflict. The period is limited to the first days of NATO operations, i.e. 24-26 March 1999. In a forthcoming second stage of our research we will complement this pilot study with a diachronical analysis.

Our key findings concern the relations between the discourse on Kosovo in the four newspapers (1) between themselves and (2) compared to the propaganda discourse of the parties involved. The general conclusion is that 'national' variations are clearly visible in the material. So, with respect to the local appropriation of meanings in the transnational propaganda flow the case is strongly confirmed. Whether that also falsifies the cultural imperialism theory's notion of US ideological dominance, as is sometimes implied, is another matter. As we see it, that is an empirical question which is not answered by simply the observation of different images of the conflict in different local/national contexts. The crux of the matter is how these images vary, and here also in comparison with the conflict image in Clinton's speeches. Let us then summarize the variations between the Kosovo discourses of the four dailies.

In general terms and with respect to two central elements in Clinton's speeches, i.e. (1) the necessity of the bombings to make Milosevic stop ethnic cleansing and (2) that the responsibility for the hostilities lies solely with Milosevic, the NATO/US propaganda view was privileged and even reinforced by the dailies from Norway, Sweden and the UK in our sample. In one instance - the association between Milosevic and Hitler as indicated by Clinton — is even further elaborated on by the media. A third element, i.e. the peace-enforcing objective of 
the NATO involvement, is on the whole uncritically promoted in the British and Norwegian dailies, but strongly questioned in the Swedish and the Greek newspapers. The Greek daily, however, is the only one in the sample where the NATO/US discourse is directly countered by a predominantly critical discourse entirely questioning its rationality and legitimacy.

To summarize, four main points can be noted:

1. The Swedish paper deviates significantly from its British and Norwegian counterparts, particularly in terms of its frequent prognoses of negative outcomes for the NATO operations. Neither the British nor the Norwegian media come anywhere near the Swedish paper's estimates with regard to civilian or military casualties or its dystopian worries about the bombings spreading the hostilities to other countries, leading to a new Cold War or even to a Third World War. Together with this specific 'Swedish' focus on catastrophic consequences is a concern for the civilian population in Kosovo and in Serbia. Thus, the 'Swedish' discourse takes a more critical position than the Norwegian and British newspapers, but less than the 'Greek' discourse.

2. The legality and legitimacy problems of the NATO operations are taken up relatively extensively in the Greek and the two Scandinavian dailies, particularly the Swedish paper. In the British daily, however, the lack of a UN Security Council sanction is pushed backstage. It is notably overshadowed by the government's declarations that the operations are in tune with the UN, unofficially, if not actually supported by the UN.

3. When the bombing campaign is criticized by the British paper, it is mainly because it is not efficient enough to stop ethnic cleansing in Kosovo. According to the British discourse, for that to happen, ground forces are a viable option. This argument is not at all as central in the other media as it is in the British daily, although Carl Bildt did actually raise it in the Swedish discourse.

4. With respect to the events immediately preceding the NATO attacks, the media coverage is marked by two important omissions. The content of the Rambouillet Accord, Appendix B, is not mentioned in any of the dailies during the period studied. The Serbian parliament's peace initiative of 23 March is only mentioned by the Greek newspaper. In the Swedish daily, only 
the militant element of the statement, i.e. Serbia's declaring that it will resist any attack on its territory, is reported.

This is an example of the impact on media coverage of propaganda in the forms of 'gray propaganda' or disinformation (Jowett and O'Donnell, 1992: 13) as methods for 'mobilisation of bias' (Bachrach and Baratz, 1970). Censuring these two pieces of information was crucial in order to establish the image of the Belgrade regime as the intransigent side in the conflict. After this successful act of propaganda, the subsequent NATO persuasion campaign had the advantage. Providing that this enemy image was accepted it was reasonable for international opinion to tolerate the NATO bombing campaign. The problem remains, however, that this was not the complete picture, but a delusive image, and, therefore, it is fair to say that public opinion was deliberately misled. The fact that such neglect was in some minor ways corrected after the war does not change this conclusion, since at that time the propaganda objectives had already been achieved.

\section{A final note}

The study reported here is a pilot study within a larger project. In the next step the media discourses will be compared diachronically. One of the questions for the coming analyses is whether the 'national' media discourses converge towards the dominant NATO/US discourse, similar to what previous research results from the Persian Gulf War indicate. Not until we have finished these additional studies will it be possible to make a proper assessment of discursive dominance in the Kosovo propaganda war.

\section{Notes}

1. The 25 March is the Greek National Liberation Day and it is therefore a bank holiday, so the examination of the Greek paper is restricted to the issues of 24 and 26 March.

2. Besides the thematic priorities, a note on the way quotations and accounts of the media texts are used might be in place. When trying to present a representative picture of the media content typical text elements have been selected, considering basic criteria for validity in interpretations: legitimacy, correspondence, generic appropriateness, and coherence (see Hirsch, 1967: 238). In this study the criteria of correspondence is probably most important to mention, since it demands that a valid interpretation must consider all linguistic elements of the text, and also give them adequate representation. 
However, in our representation of the media content we have, for sake of effective comparisons and usage of space, exposed 'cross-national' differences more than similarities. Hence, characteristics common for all the papers studied, e.g. direct reports of the Clinton speeches, have not been our focus. That is a consequence of our theoretical aims. But this does not imply that a characteristic of the content that is exclusively ascribed to one or more particular newspapers, will also be present in any of the other newspapers studied.

3. See 'Remarks by the President to AFSCME Biennial Convention', Omni Shoreham Hotel, Washington DC, and 'Statement by the President to the Nation', The Oval Office. Available at http://www.pub.whitehouse.gov/urires/I2R?urn:pdi://oma.eop.gov.us/

4. See The Daily Telegraph, 'It's Right to Fight this War' (27 March 1999: 22). Due to the significance of the Second World War in British culture, it is not uncommon to refer to appeasement as a lesson learned and not to be repeated in future conflicts. Mrs Thatcher used the same argument about not allowing aggressors to succeed during the Falklands War. See also Robertson (1992).

5. An article on 13 June in The Daily Telegraph, 'How Blair Led Nato to Victory - Over Clinton', argues that due to poor leadership by the US president and the fear of casualties, it was the British prime minister Tony Blair who really 'held Nato together' (The Daily Telegraph, 13 June 1999: 18).

\section{References}

Bachrach, P. and M. Baratz (1970) Power and Poverty. New York: Oxford University Press.

Bennett, W. Lance and David L. Paletz (eds) (1994) Taken By Storm: The Media, Public Opinion, and US Foreign Policy in the Gulf War. Chicago, IL: The University of Chicago Press.

Chomsky, Noam (1999) The New Military Humanism. Lessons from Kosovo. Monroe, ME: Common Courage Press.

Fairclough, Norman (1995) Media Discourse. London: Edward Arnold.

Goff, Peter (1999) 'Introduction', The Kosovo News and Propaganda War. Vienna: The International Press Institute.

Hirsch, Eric D. Jr (1967) Validity in Interpretation. London: Yale University Press.

Jowett, Garth S. and Victoria O’Donnell (1992) Propaganda and Persuasion. London: Sage.

McNair, Brian (1999) News and Journalism in the UK. London: Routledge.

Nohrstedt, Stig A. (1986) Tredje världen i nyheterna. Stockholm: Almqvist and Wiksell International.

Nohrstedt, Stig A. and Rune Ottosen (eds) (forthcoming) Journalism and the New World Order. Gulf War, National News Discourses and Globalization. Göteborg: Nordicom. 
Robertson, A. (1992) National Prisms and Perceptions of Dissent. The Euromissile Controversy Reflected in Opinion and the News in the UK and FRG 1980-83. Edsbruk: Akademitryck.

Seymour-Ure, Colin (1996) The British Press and Broadcasting since 1945, 2nd edn. Oxford: Blackwell.

Taylor, Philip M. (1997) Global Communications, International Affairs and the Media since 1945. London: Routledge.

Thompson, John B. (1995) The Media and Modernity. A Social Theory of the Media. Cambridge: Polity Press.

Van Dijk, Teun (1991) 'The Interdisciplinary Study of News as Discourse', pp. 108-20 in Klaus B. Jensen and Nicholas W. Jankowski (eds) A Handbook of Qualitative Methodologies for Mass Communication Research. London: Routledge.

Wodak, Ruth, Rudolf de Cilla, Martin Reisigl and Karin Liebhart (1999) The Discursive Construction of National Identity. Edinburgh: Edinburgh University Press. 